\title{
Commentary: Blood transfusions in transcatheter aortic valve replacement-Less is more
}

\author{
Hiroto Kitahara, MD, J. James Edelman, MBBS(Hons), PhD, and Vinod H. Thourani, MD
}

\footnotetext{
From the Department of Cardiac Surgery, MedStar Heart and Vascular Institute, Georgetown University, Washington, DC

Disclosures: Authors have nothing to disclose with regard to commercial support.

Received for publication March 25, 2019; accepted for publication March 26, 2019; available ahead of print May $14,2019$.

Address for reprints: Vinod H. Thourani, MD, Department of Cardiac Surgery, 110 Irving St, Suite 6D15G, Washington, DC 20010 (E-mail: vinod.h.thourani@medstar.net).

J Thorac Cardiovasc Surg 2020;159:112-3

$0022-5223 / \$ 36.00$

Copyright (c) 2019 by The American Association for Thoracic Surgery

https://doi.org/10.1016/j.jtcvs.2019.03.108
}

The need for red blood cell (RBC) transfusion during transcatheter aortic valve replacement (TAVR) is the result of a major vascular complication or of a life-threatening, disabling, or major bleeding event. In this issue of the Journal, Kolte and colleagues ${ }^{1}$ report a large, retrospective cohort study in which they investigated the rates, trends, and predictors of RBC transfusion in high-risk and extreme-risk patients with severe aortic stenosis undergoing TAVR between January 2012 and September 2015. To review all patients undergoing TAVR, they accessed the National Impatient Sample (NIS) database, the largest publicly available all-payer inpatient healthcare database in the United States. During the period of the study, the rates of RBC transfusion decreased from $29.5 \%$ to $10.8 \%$. Preoperative anemia, older age, female sex, peripheral vascular disease, chronic kidney disease, and coagulopathy were detected as independent predictors of RBC transfusion in TAVR. Propensity-matched analysis detected higher complication rates in patients without bleeding who received RBC transfusion compared with those who did not; however, these differences were not seen in patients with overt bleeding.

Despite the less invasive nature of transcatheter techniques relative to surgical aortic valve replacement, vascular mishaps or other comorbidities may require blood transfusion in TAVR. Previously, this same group from Brown University published a single-center study of RBC transfusion in TAVR and showed that transfusion in TAVR was associated with higher morbidity and mortality. ${ }^{2}$ Although the initial rate of blood transfusion in firstgeneration TAVR systems has been reported at approximately $30 \%$ to $40 \%,{ }^{3-6}$ the advent of improved technology and decreasing sheath size has increased the rate of percutaneous transfemoral techniques and therefore decreased the rates of blood transfusion, as also shown by the current work of Kolte and colleagues. ${ }^{1}$ Report of the Society of Thoracic Surgeons and American College of Cardiology Transcatheter Valve Therapy Registry system.

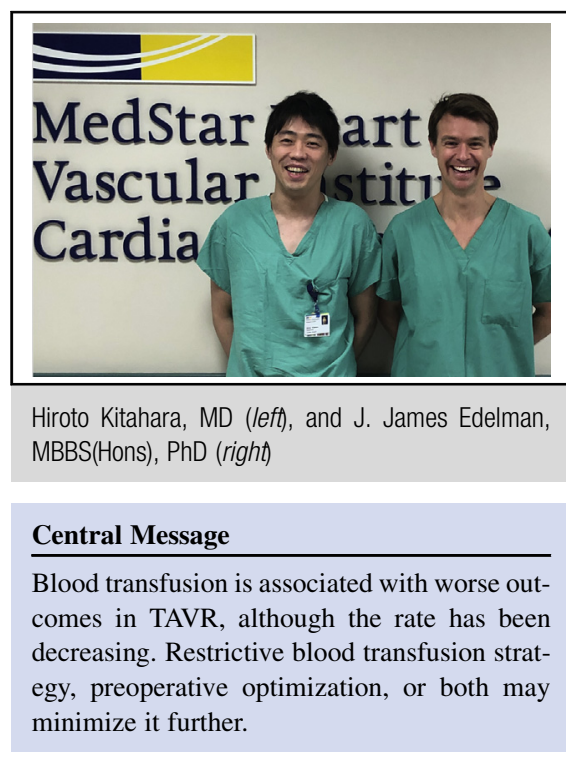

See Article page 102

showed similar trends, with reduction in the rate of blood transfusion in TAVR from $45 \%$ in 2012 to $22 \%$ in $2015 .^{6}$ This trend might have been driven by combination of change in patients' risk profile (inoperable and high to intermediate), increased use of a transfemoral approach, and the use of low-profile sheaths, minimizing the risk of vascular access complications. Most recently, we have noted only a $2.0 \% \mathrm{RBC}$ transfusion rate at 30 days for low-risk patients undergoing transfemoral TAVR with the third-generation

What can we do to decrease further the rate of blood transfusion and improve the outcome of TAVR? Restrictive transfusion strategy is one of the key factors to achieve this goal. To date, there are no transfusion guidelines for patients undergoing percutaneous TAVR. The threshold for blood transfusion in TAVR varies, and no definitive criteria exist. Many investigators have tried to create a threshold and attempted restrictive transfusion strategy to decrease unnecessary transfusions in cardiac surgery, but not for TAVR. Mori and colleagues ${ }^{8}$ recently published a $52 \%$ reduction of blood transfusion requirement with their restrictive transfusion strategy, without any difference in postoperative outcomes. Preoperative hemoglobin optimization is another interesting topic. Many investigations have reported that preoperative anemia is an independent 
predictor of blood transfusion in $\mathrm{TAVR}^{1,5,9}$; therefore, hemoglobin optimization or an anemic workup may be beneficial to minimize postoperative blood transfusion. To perform TAVR safely for a specific group of patients refusing blood transfusion, Binder and associates ${ }^{9}$ set the preoperative hemoglobin goal to more than $12.0 \mathrm{~g} / \mathrm{dL}$, and hemoglobin optimization was achieved with erythropoietin or iron supplement therapy. These protocols would be beneficial not only for the specific group of patients refusing transfusion, but also for other patients with preoperative anemia undergoing TAVR.

We congratulate Kolte and colleagues ${ }^{1}$ for providing provocative data from one of the largest cohorts undergoing TAVR in the United States. Although it was observational study involving some confounding factors that may have affected the outcomes, this report highlights the clinical management of patients undergoing TAVR and further investigations to minimize blood transfusion.

\section{References}

1. Kolte D, Beale C, Aronow HD, Kennedy KF, Apostolidou E, Sellke FW, et al. Trends and outcomes of red blood cell transfusion in patients undergoing transcatheter aortic valve replacement in the United States. J Thorac Cardiovasc Surg. 2020;159:102-11.e11.
2. Apostolidou E, Aronow HD, Beale CE, Kolte D, Kennedy KF, Sellke FW, et al Association between red blood cell transfusion and clinical outcomes among patients undergoing transcatheter aortic valve replacement. Ann Thorac Surg. December 12, 2018 [Epub ahead of print].

3. Tchetche D, Van der Boon RM, Dumonteil N, Chieffo A, Van Mieghem NM, Farah B, et al. Adverse impact of bleeding and transfusion on the outcome posttranscatheter aortic valve implantation: insights from the Pooled-RotterdAmMilano-Toulouse In Collaboration Plus (PRAGMATIC Plus) initiative. Am Heart J. 2012;164:402-9.

4. Seiffert M, Conradi L, Terstesse AC, Koschyk D, Schirmer J, Schnabel RB, et al Blood transfusion is associated with impaired outcome after transcatheter aortic valve implantation. Catheter Cardiovasc Interv. 2015;85:460-7.

5. Nuis RJ, Sinning JM, Rodés-Cabau J, Gotzmann M, van Garsse L, Kefer J, et al. Prevalence, factors associated with, and prognostic effects of preoperative anemia on short- and long-term mortality in patients undergoing transcatheter aortic valve implantation. Circ Cardiovasc Interv. 2013;6:625-34.

6. Grover FL, Vemulapalli S, Carroll JD, Edwards FH, Mack MJ, Thourani VH, et al; STS/ACC TVT Registry. 2016 annual report of the Society of Thoracic Surgeons/ American College of Cardiology transcatheter valve therapy registry. J Am Coll Cardiol. 2017;69:1215-30

7. Mack MJ, Leon MB, Thourani VH, Makkar R, Kodali SK, Russo M, et al; PARTNER 3 Investigators. Transcatheter aortic-valve replacement with a balloon-expandable valve in low-risk patients. N Engl J Med. March 17, 2019 [Epub ahead of print].

8. Mori M, Zhuo H, Liu F, LaLonde M, Pelletier KJ, Agarwal R, et al. Predictors of cardiac surgery patients who tolerate blood conservation in cardiac surgery. Ann Thorac Surg. January 9, 2019 [Epub ahead of print].

9. Binder RK, Barbanti M, Ye J, Toggweiler S, Tan J, Freeman M, et al. Blood loss and transfusion rates associated with transcatheter aortic valve replacement: recommendations for patients who refuse blood transfusion. Catheter Cardiovasc Interv. 2014;83:E221-6. 